Theological Research • volume 5 (20I7) ・ P. 4I-53 doi: http://dx.doi.org/10.15633/thr.3300

\author{
Angelika Maria Maeek
}

The Pontifical University of John Paul II in Krakow

\title{
Imago Christi \\ or "just" Imago Mariae? \\ Women and the Problem of Image and Imitation
}

\begin{abstract}
The main question discussed in this paper is: Can we say that, in the light of orthodox Catholic theology, woman is an image of Christ in a way equal to man? How Jesus and His Mother should be treated as examples for imitation for Christians of both sexes on this ground? The first part of the article explains the terms imago Dei and imago Christi, and connection between them in their biblical, dogmatical, and contemporary theological-anthropological context, the last one understood strictly as anthropology in documents of the Catholic Magisterium published during and after II Vatican Council. The second part concerns the problem of Jesus and Mary as models for men, and/or women in the present day, on the basis of Church documents, especially Mariological ones. The third part considers the problem of women as imago Chris$t i$ in the light of Catholic feminist theology. Conclusions are proposed at the end of the paper.
\end{abstract}

\section{KeYwords}

Jesus Christ, Mary, woman, image, model, imitation 
As in every rightly understood theology, the question asked in the topic of this paper is not only a theoretical problem, but has its practical consequences, too. When both sexes are imago Dei, but only one can be imago Christi and the second traditionally gets Mary (in her earthly life, deeply rooted in her historical and cultural context) as the model to imitate, it is impossible to hold they are equal in being imago Dei. But what can we draw from the contemporary doctrine of the Catholic Church in regard to: I) woman as truly being imago Christi, 2) Mary as a model for whole humankind, not only woman, but man too, and 3) how the connection between imago Christi and imago Mariae looks in this context, especially in the light of the Catholic feminist theology which proclaims true humanity and equality of women and men?

\section{In Whose Image? Connections between IMAGO DEI AND IMAGO CHRISTI}

Only Christ as the Son of God is the real image of God the Father. On the other hand, His Mother is the most excellent example of being a Christian and being a woman; but can we really say that Jesus is a model for men and Mary for women, as it is deeply rooted in the Christian (Catholic) pastoral tradition? In the first part of this article, a biblical, dogmatical, and anthropological basis for further reflection on the topic of women as imago Christi will be presented.

"God created man in the image of himself, in the image of God he created him, male and female he created them" (Genesis I, 27). ${ }^{\text {T This }}$ truth, fundamental for Christian anthropology, is repeated in further parts of the Old Testament, as well (for example cf. Wisdom 2, 23; Sirach I7, 3). The New Testament presents Jesus as the One Who is connected with God in the most excellent way: “... you will know that $\mathrm{I}$ am He and that I do nothing of my own accord. What I say is what the Father has taught me" (John 8, 28). The Father and Jesus are one (cf. John Io, 30) and whoever sees the Son, sees the Father, so after the Incarnation nobody can say "show us the Father" any more (cf. John I2, 45; I4, 9). In Hebrews Jesus is "the reflection of God's glory and bears

I The translation of the Bible used in this article is the New Jerusalem Bible (NJB), I985 (except for the Church Magisterium documents, where the versions of authors' choice have been left). 
the impress of God's own being" (Hebrews 1,3 ). Paul names Jesus "the image of God" (2 Corinthians 4,4$)$. But what is most important, is in Colossians, where the Son of God is presented as

[...] the image of the unseen God, the first-born of all creation, for in him were created all things in heaven and on earth: everything visible and everything invisible, thrones, ruling forces, sovereignties, powers - all things were created through him and for him. [...] He is the Beginning, the first-born from the dead, so that he should be supreme in every way; because God wanted all fullness to be found in him and through him to reconcile all things to him, everything in heaven and everything on earth, by making peace through his death on the cross (Colossians I, 15-16.18b-20).

Chalcedonian Definition (45I) simply states that:

our Lord Jesus Christ is to us One and the same Son, the Self-same Perfect in Godhead, the Self-same Perfect in Manhood [ $\alpha \dot{v} \theta \rho \omega \pi$ ó $\eta \tau \tau$, bumanitate]; truly God and truly Man [öv $\theta \rho \omega \pi \mathrm{ov}$, hominem $] ;[. .$.$] co-$ essential with the Father according to the Godhead, the Self-same co-essential with us according to the Manhood; like us in all things, sin apart; before the ages begotten of the Father as to the Godhead, but in the last days, the Self-same, for us and for our salvation (born) of Mary the Virgin Theotokos as to the Manhood; One and the Same Christ, Son, Lord, Only-begotten; acknowledged in Two Natures unconfusedly, unchangeably, indivisibly, inseparably. ${ }^{2}$

As we can see, this dogmatical definition does not concentrate on any particular physical aspects, but "only" proclaims true humanity of Jesus, without further emphasis. Contemporarily, the problem of imago Christi has gained an important position in the reflection about the possibility of ordination for women. It is clear that anthropological argumentation is not only connected with this case, but has further consequences which are important in reflection about role and place of women in the Church and in Salvation. The Congregation for the Doctrine of the Faith in its famous Declaration on the Question

2 The Oecumenical Documents of the Faith. The Creed of Nicaea. Three Epistles of Cyril. The Tome of Leo. The Chalcedonian Definition, ed. T. H. Bindley, London r899, p. 297. 
of Admission of Women to the Ministerial Priesthood Inter insigniores stated that in the light of fact that "Christ himself was and remains a man,"

the priest is a sign $[\ldots]$, but a sign that must be perceptible and which the faithful must be able to recognise with ease. The whole sacramental economy is $[\ldots]$ based upon natural signs $[\ldots]$ : when Christ's role in the Eucharist is to be expressed sacramentally, there would not be this "natural resemblance" which must exist between Christ and his minister if the role of Christ were not taken by a man: in such a case it would be difficult to see in the minister the image of Christ [imago Christi].

Christ is "the firstborn of all humanity" - women and men, so there are no more distinctions between Jew and Greek, slave and free, too, but all are one in Jesus Christ, as Galatians 3, 28 says. "Nevertheless, the incarnation of the Word took place according to the male sex [...] and this fact, while not implying any alleged natural superiority of man over woman, cannot be disassociated from the economy of salvation." It is the part of the entirety of God's plan, of which "the mystery of the Covenant is the nucleus." 3 How does this anthropological opinion used for explaining no ordination for women - influence whole theology, not only the part connected with the main problem of this quoted document, but much deeper aspects, as well?

3 Congregation for the Doctrine of the Faith, Declaration on the Question of $A d$ mission of Women to the Ministerial Priesthood “Inter insigniores”, „Acta Apostolicae Sedis” 69 (1977), pp. 98-II6, n. 5 (all English quotations from contemporary Church documents come from the official website of the Holy See: vatican.va). The main idea of the declaration, i.e. the relevance of Jesus' gender, has been repeated in the next document of Congregation, namely Letter to the Bishops of the Catholic Church on the Collaboration of Men and Women in the Church and in the World, „Acta Apostolicae Sedis” 96 (2004), pp. 67I-687, n. 3, 9-Io. 
2. Contemporary Meaning of Jesus' and Mary's Models ${ }^{4}$

As Karl Rahner wrote, "Christology is the end and beginning of anthropology [...] this anthropology, when most thoroughly realized in Christology, is eternally theology." 5 We can understand Jesus as the model for people in many different ways. He is the example of the relationship with the Father both as a human and as the Second Person of the Trinity. He is the Second Adam, but, at the same time, also his image and the First of all beings ("the first-born of all creation," as Paul said in Colossians I, I5) because of His realization of human nature which is the prototype for all other people (both men and women).

When preaching His Gospel, Jesus did not give examples for men and for women separately. In parables both sexes are given as examples for all people (the poor widow and the judge (cf. Luke I8, I-8), the friend coming at night (cf. Luke II, 5-8)) and as images of God himself, too (the good shepherd (cf. Luke I5, I-7, Matthew I8, I2-I4, John IO, I-I8) or the drachma seeker (cf. Luke I5, 8-IO)). Real people whose meetings with Jesus caused their conversion (or were consequences of it) are not divided into the female and male disciples. We know that from descriptions of anointing by Mary from Bethany (cf. Mark I4, 3-9; Matthew 26, 6-I3; John I2, I-8) and by another, nameless woman (cf. Luke 7, 36-50), dialogues with the Samaritan (cf. John 4, I-26) and Syrophoenician (cf. Mark 7, 24-30, Matthew 15, 2I-28) women, the story of the widow of Nain (cf. Luke $7, \mathrm{II}-\mathrm{I} 7$ ), and the case of the woman with the issue of blood (cf. Mark 5, 2I-34; Matthew 9, I8-22; Luke 8, 40-48).

The Second Vatican Council in the Dogmatic Constitution on the Church Lumen Gentium calls a martyr a disciple who "is transformed into an image of his Master [Magistro... assimilatur] by freely accepting death for the salvation of the world." ${ }^{6}$ We can name Jesus the most

4 "Contemporary" means the time during and after II Vatican Council in this case.

5 K. Rahner, On the Theology of the Incarnation, in: Theological Investigation, vol. 4, London-Baltimore I966, p. II\%.

6 II Vatican Council, Dogmatic Constitution on the Church Lumen Gentium, „Acta Apostolicae Sedis” 57 (1965), pp. 5-75, n. 42. 
ideal Love, and Mary the perfect human answer to this Love. ${ }^{7}$ Jesus calls Himself the Way, the Truth, and the Life, the only One who can offer the possibility to meet the Father (cf. John I4, 6), and Mary teaches us to do whatever He tells (cf. John 2, 5).

The eighth chapter of Lumen Gentium is dedicated to Mary. It says, that the Virgin is

Redeemed [in the original Latin version: sublimiore modo redempta, "in

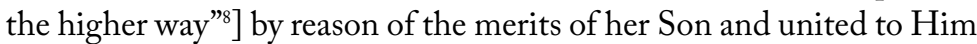
by a close and indissoluble tie, she is endowed with the high office and dignity of being the Mother of the Son of God, by which account she is also the beloved daughter of the Father and the temple of the Holy Spirit. Because of this gift of sublime grace she far surpasses all creatures, both in heaven and on earth. [...] she is hailed as a pre-eminent and singular member of the Church, and as its type and excellent exemplar in faith and charity. ${ }^{9}$

In the apostolic exhortation Signum Magnum, Paul vi reminds all Catholics that "imitation of the Virgin Mary, far from distracting the souls from the faithful following of Christ, makes it more pleasant and easier for them." ${ }^{\circ}$ But what is most important here, is that he calls Mary "the most faithful image" [accuratissime expressa imago] of His Son. ${ }^{\text {II }}$

In a different apostolic exhortation, Marialis Cultus, Paul vi named Mary "a teacher of the spiritual life for individual Christians." Mary is,

7 Cf. Paul vi, Apostolic Exhortation Marialis cultus, „Acta Apostolicae Sedis”66 (1974), pp. I13-168, n. I6: "That the Blessed virgin is an exemplar in this field derives from the fact that she is recognized as a most excellent exemplar of the Church in the order of faith, charity and perfect union with Christ, that is, of that interior disposition with which the Church, the beloved spouse, closely associated with her Lord, invokes Christ and through Him worships the eternal Father." Cf. in Vatican Council, Lumen Gentium, n. 63 and II Vatican Council, Constitution on the Sacred Liturgy Sacrosanctum Concilium, „Acta Apostolicae Sedis” 56 (1964), pp. 97-I38, n. 7.

8 Pius XII in his encyclical Fulgens Corona teaches that "Christ the Lord in a certain most perfect [perfectissimo] manner really redeemed His mother." Pius XII, Encyclical Fulgens Corona, „Acta Apostolicae Sedis” 45 (1953), pp. 577-592, n. I4.

9 II Vatican Council, Lumen Gentium, n. 53.

Io Paul vi, Apostolic Exhortation Signum Magnum, „Acta Apostolicae Sedis” 59 (I967), pp. 465-475, II.

II Cf. Paul vi, Signum Magnum, I. 
above all, the example of worship by replying to the God's messenger: "I am the handmaid of the Lord. Let what you have said be done to me" (Luke I, 38). Mary's "yes" is for all Christians a lesson of obedience to the will of God. ${ }^{\mathrm{I} 2}$ But devotion to the Virgin should keep up with modern anthropological discoveries and changes. Because of Mary's portrayal presented in a certain type of devotion, some people are becoming disenchanted with devotion to the Virgin in general and with taking her as an example in particular. ${ }^{13}$ Mary is proposed to be imitated not for the type of life she lived in her socio-cultural background, but for her full and responsible acceptance of God's will (cf. Luke I, 38). She is a worthful example as "the first and the most perfect of Christ's disciples," which has permanent and universal value. ${ }^{\mathrm{I} 4}$ Christians have found the type of womanhood in Mary as a virgin, wife, and mother. ${ }^{15}$

Today, Christians are called upon to compare the contemporary anthropology and its problems with the Gospel image of the Virgin. Reading of the Bible, carried out with the discoveries of the sciences and the different situations in the world today in our minds, will help to see how Mary can be considered a mirror of the expectations of men and women of our time. A modern woman can simply contemplate Mary who gives God her active and responsible consent to Incarnation of the Word and her courageous choice of virginity. In her devotion to the will of God, Mary was far from being a submissive woman or, simply stated, a bigot. On the contrary, Mary was somebody who proclaims the power of God and His liberation prepared for the humble and the oppressed, when the people of power will be removed from their privileged positions (cf. Luke I, 5I-53). Mary can be recognized today as a woman of strength who experienced difficult life situations (cf. Matthew 2, 13-23). Today, the Virgin and Mother of the Son of God, and our Mother can be the perfect model of the disciple of the Lord, who builds up earthly Jerusalem while being a pilgrim towards the heavenly one and, above all, who is a witness of Christ's love. ${ }^{16}$ Mary is one of us and our sister who fully shared our life as a poor and

I2 Cf. Paul vi, Marialis cultus, n. 2I.

I3 Cf. Paul vi, Marialis cultus, n. 34 .

I4 Cf. Paul vi, Marialis cultus, n. 35 .

I5 Cf. Paul vi, Marialis cultus, n. 36.

I6 Cf. Paul vi, Marialis cultus, n. 37. Cf. II Vatican Council, Lumen Gentium, n. 5556 and Paul vi, Signum Magnum, I. 
humble woman, but the one free from mother Eve's sin. ${ }^{17}$ According to the Bible, Jesus is "the only way to the Father" (cf. John I4, 4-II) and "the ultimate example to whom the disciple must conform his own conduct" (cf. John I3, I5). ${ }^{18}$

The "song of protest," Magnificat (cf. Luke I, 46-55), corresponds with Jesus' preaching about the coming of the Kingdom of the poor (cf. Matthew I9, 24; Luke 6, 20-2I). As Rosemary Radford Ruether wrote, according to the Gospel of Luke, Mary is chosen by God both as a subject (through her act of faith) and as an object (as a human being) of His liberating revolution in history, the revolution in human relationships. ${ }^{19}$ In this light, a great threat to Mariology is treating Mary as a "competitor" to the title of the Only Mediator. Virgin's answer to God was most excellent, but as human choice it was one among many. In this perspective we can understand Mary's "life and work" as her being prima inter pares, a Sister in her equality with other people, but the Mother as the first Christian and the first redeemed. ${ }^{20}$ As Lumen Gentium says, Mary "is hailed as a pre-eminent and singular member of the Church, and as its type and excellent exemplar in faith and charity." ${ }^{21}$

\section{Women as Imago Christi in the Catholic Feminist Theology}

This part of the article will refer to Catholic feminist theologians' reception of contemporary Church's teaching connected with the problem of imago Christi. Because of the limited volume, it will be not a comprehensive analysis, obviously, but references to only two, yet, important and representative of this trend in theology, American researchers will

I7 Cf. Paul vi, Marialis cultus, n. 56.

I8 Paul vi, Marialis cultus, n. 57 .

I9 Cf. R. R. Ruether, Sexism and God-Talk. Toward a Feminist Theology, Boston I983, p. I55.

20 Immaculate Conception is here the most important aspect of the fact that Mary, "in view of the merits of Jesus Christ, the Savior of the human race, was preserved free from all stain of original sin." Pius Ix, Bull Ineffabilis Deus, 8th December I854.

2I II Vatican Council, Lumen Gentium, n. 53. 
be made: already mentioned Rosemary Radford Ruether and Elizabeth A. Johnson.

Nam quod assumptum non est, curationis est expers, Gregory of $\mathrm{Na}-$ zianzus wrote in his famous sentence. ${ }^{22}$ But reflection made in the light of the equal rights of men and women is quite new in theological anthropology. Claiming full human identity as both imago Dei and imago Christi for women is the center of gravity for feminist discourse in theology. ${ }^{23}$ Ruether wrote that:

Whatever denies, diminishes, or distorts the full humanity of women is, therefore, appraised as not redemptive. Theologically speaking, whatever diminishes or denies the full humanity of women must be presumed not to reflect the divine or an authentic relation to the divine, or to reflect the authentic nature of things, or to be the message or work of an authentic redeemer or a community of redemption. ${ }^{24}$

In this reflection concepts of imago Dei/imago Christi defined as a male humanity above female lower-class humanity is far more an "instrument of sin" rather than an "instrument of grace." ${ }^{25}$ The emphasis on Jesus' maleness is, in her opinion, not compatible with the Gospel, where the sex is only one of many characteristics describing Christ. ${ }^{26}$ What is more, the Gospel does not operate with the dualism of masculine and feminine - they are just elements of social life like many others, e.g. class or ethnicity. Finally, Jesus' maleness does not have any "ultimate significance." ${ }^{27}$

Johnson sees the problem with the imago doctrine in gender dualism found in Hellenistic thought - Christianity has always been affirming

22 Grégoire de Nazianze (Gregory of Nazianzus), Lettre IOI, 32 (Du même, au prêtre Clédonios, première lettre), in: Grégoire de Nazianze, Lettres Théologiques, Paris 1974, pp. 50-5I (Sources Chrétiennes, 208); Gregorii Theologi (Gregory of Nazianzus), Epistola CI (Ad Cledonium Presbyterum contra Apollinarium, epistola I), in: Gregorii Theologi, Opera quae exstant omnia, Turnholti I990, cols. I8I-I83 (Patrologia Graeca, 37).

23 Cf. E. A. Johnson, She Who Is. The Mystery of God in Feminist Theological Discourse, New York 1994, p. 62.

24 R. R. Ruether, Sexism and God-Talk..., op. cit., pp. I8-I9.

25 Cf. R. R. Ruether, Sexism and God-Talk..., op. cit., pp. 19-20.

26 Cf. R. R. Ruether, The Liberation of Christology from Patriarchy, in: Feminist Theology. A Reader, ed. A. Loades, Louisville-London I990, p. I47.

27 Cf. R. R. Ruether, Sexism and God-Talk..., op. cit., p. I37. 
that humans are created in God's image and likeness, but the influence of Greek philosophy on theology is obvious. This dichotomization, which connects male with reason (and, as a consequence, with authority) and female with bodiliness, has led to the point where women are no more true images of God because of their lower position. ${ }^{28}$ For this author, reducing metaphors describing God to male metaphors as only suitable leads to damaging of the imago Dei in creation. ${ }^{29}$ Women, both in general and as particular persons, are "created in the image of God" as they are "bearers of the image of Christ." ${ }^{\circ}$ Johnson described understanding women as less Christomorphic because of their non-identity with the bodily form of Jesus as "naive physicalism." ${ }^{\text {I }}$ She sees one's sex only as one of the many parts of identity of a human being. Therefore, Jesus' maleness should be treated on the same ground as, for example, His ethnic or linguistic particularity, and it should be respected simply as one of them. Otherwise, we have to do with an androcentric theology and androcentric Church praxis, such that we cannot respond "yes" to the famous Ruether's question: "Can a male savior save women?" ${ }^{2}$ Johnson reminds us of the meaning of baptism which makes all Christians "ontologically identified with the death and resurrection of Christ." ${ }_{33}$ And Christ Himself after the Resurrection does not exist in a way He did in the days of His earthly life. ${ }^{34}$ The biblical meaning of being imago Christi is participating in His life, and not replication of His bodily features. Consequently, "those who live the life of Christ are icons of Christ," 35 especially martyrs through their death,

28 Cf. E. A. Johnson, She Who Is..., op. cit., p. 70.

29 Cf. E. A. Johnson, She Who Is..., op. cit., p. 36.

30 E. A. Johnson, She Who Is..., op. cit., p. 70.

3I Cf. E. A. Johnson, She Who Is..., op. cit., pp. 71-72.

32 Cf. E. A. Johnson, She Who Is..., op. cit., pp. 152-I54; R. R. Ruether, Sexism and God-Talk..., op. cit., p. II6.

33 E. A. Johnson, She Who Is..., op. cit., p. 72.

34 Cf. E. A. Johnson, She Who Is..., op. cit., p. I63.

35 E. A. Johnson, She Who Is..., op. cit., p. 72. Johnson, quoting Ruether, mentions the example of Blandina, described by Eusebius of Caesarea in Historia ecclesiastica 5.I.I-63 at 4I, Paris 1955, p. I7 (Sources Chrétiennes, 4I) - according to his relation, witnesses of her martyrdom "saw with their bodily eyes, in the form of their sister, the One who had been crucified for them”. E. A. Johnson, She Who Is..., op. cit., pp. 73-74; R. R. Ruether, Sexism and God-Talk..., op. cit., p. I3I. 
as II Vatican Council stated it. ${ }^{6}$ And the life of Christ in the world was compassionate, liberating, and in the power of the Spirit. ${ }^{37}$

\section{Conclusion}

On the basis of biblical and dogmatical truths, every human being can be described as imago Christi because of having human nature whose model and the most absolute example is Jesus. But what about Mary? We may say that her answer to God, her fiat with all its consequences, should be interpreted as the first and the most important thing about the Virgin. But this is not the final point for anybody, since discovering oneself as imago Mariae should lead every Christian to discovering themselves as imago Christi. It is so because of Mary's real uniqueness is her chosen similarity to God in Christ..$^{3}$ The connection between "You see before you the Lord's servant, let it happen to me as you have said.' And the angel left her" (Luke I, 38) and "Father,' he said, 'if you are willing, take this cup away from me. Nevertheless, let your will be done, not mine"'(Luke 22, 42) should direct us from human response to God's will, coming from the person like us, to Jesus' subordination, as the true God and a true Man, to God the Father, as He practiced it throughout His earthly life.

Both Jesus and Mary represented humankind over God. Mary did it in her response to God's offer, ${ }^{39}$ and Jesus in His Death and Resurrection for our Salvation. Therefore, taking into consideration that Mary has been described expressis verbis as the most ideal imago Christi (Paul vi chose such wording in his Signum Magnum quoted in the second part of this paper), it is not clear why, ten years later, Congregation for the Doctrine of the Faith (in its Inter insigniores, quoted in the second part, too) reserved the possibility of being a real image of Christ only for men in such an assertive manner (let us put the question of ordination of women, which is not the topic of this article, aside). The feminist

36 Cf. the second part of this article.

37 Cf. E. A. Johnson, She Who Is..., op. cit., p. 73.

38 We can talk about Christ's similarity to Mary in human categories, too, as a child who imitates his mother.

39 As Thomas Aquinas wrote in Summa Theologiae III, q.30 a.r: "in the Annunciation the Virgin's consent was besought in lieu of that of the entire human nature" [per Annuntiationem expetebatur consensus virginis loco totius humanae naturae]. 
theology concentrates over the question of women as imago Christi, but in spite of biblical and dogmatical analysis which is in general identical with „mainstream” Catholic theology, finally there is no consent with this statement of Congregation and their possible practical consequences.

\section{BiBLIOGRAPHY}

Congregation for the Doctrine of the Faith, Declaration on the Question of $A d-$ mission of Women to the Ministerial Priesthood "Inter insigniores”, „Acta Apostolicae Sedis" 69 (1977), pp. 98-Ir6.

Congregation for the Doctrine of the Faith, Letter to the Bishops of the Catholic Church on the Collaboration of Men and Women in the Church and in the World, „Acta Apostolicae Sedis” 96 (2004), pp. 671-687.

Eusèbe de Césarée (Eusebius of Caesarea), Histoire ecclésiastique V-VII, in: Eusèbe de Césarée, Histoire ecclésiastique, vol. 2, Paris 1955 (Sources Chrétiennes, $4 \mathrm{I}$ ).

Grégoire de Nazianze (Gregory of Nazianzus), Lettre IOI,32 (Du même, au prêtre Clédonios, première lettre), in: Grégoire de Nazianze, Lettres Théologiques, Paris 1974 (Sources Chrétiennes, 208).

Gregorii Theologi (Gregory of Nazianzus), Epistola CI (Ad Cledonium Presbyterum contra Apollinarium, epistola I), in: Gregorii Theologi, Opera quae exstant omnia, Turnholti 1990 (Patrologia Graeca, 37).

Johnson E. A., She Who Is. The Mystery of God in Feminist Theological Discourse, New York 1994.

New Jerusalem Bible, 1985.

Paul vi, Apostolic Exhortation Signum Magnum, „Acta Apostolicae Sedis” 59 (1967), pp. 465-475.

Paul vI, Apostolic Exhortation Marialis cultus, „Acta Apostolicae Sedis” 66 (1974), pp. II3-I68.

Pius Ix, Bull Ineffabilis Deus, $8^{\text {th }}$ December 1854 .

Pius XII, Encyclical Fulgens Corona, „Acta Apostolicae Sedis” 45 (1953), pp. 577592.

Rahner K., On the Theology of the Incarnation, in: Theological Investigation, vol. 4, London-Baltimore 1966, pp. I05-I20.

Ruether R. R., Sexism and God-Talk. Toward a Feminist Theology, Boston 1983.

Ruether R. R., The Liberation of Christology from Patriarchy, in: Feminist Theology. A Reader, ed. A. Loades, Louisville-London 1990, pp. I38-I48. 
The Oecumenical Documents of the Faith. The Creed of Nicaea. Three Epistles of Cyril. The Tome of Leo. The Chalcedonian Definition, ed. T. H. Bindley, London 1899.

Thomas Aquinas, The Summa Theologica, trans. Fathers of the English Dominican Province, 1947.

II Vatican Council, Constitution on the Sacred Liturgy Sacrosanctum Concilium, „Acta Apostolicae Sedis” 56 (1964), pp. 97-г38.

II Vatican Council, Dogmatic Constitution on the Church Lumen Gentium, „Acta Apostolicae Sedis” 57 (1965), pp. 5-75. 